\title{
Decrease in the Insulin of Rabbit Pancreas in Late Pregnancy
}

\author{
C. Lopez-Quijada, J. Gomez-Acebo and J.L. R-CANDELA \\ Instituto "G. Marañon", Consejo Superior de Investigaciones Científicas. Madrid, Spain \\ Received January 30, 1967
}

Summary. Plasma insulin levels and extractable insulin of the pancreas of normal and pregnant rabbits have been studied. - The mean plasma insulin of non-pregnant controls was $25 \mu \mathrm{U} / \mathrm{ml}$ (range 18 to 33 ); extractable pancreas insulin was $3.56 \mu \mathrm{g} / 100 \mathrm{mg}$ tissue $(3.33$ to 3.76$)$. The insulin level in the blood increases during late preg. nancy to $56 \mu \mathrm{U} / \mathrm{ml}$ (range 37 to 81 ) and the extractable pancreatic insulin decreases to $1.17 \mu \mathrm{g} / 100 \mathrm{mg}$ tissue (0.65 to 1.73). - The fine structure of B and A-cells has been studied in pregnancy: insulin stored in B granules decreases and the A-cells show definite signs of increased activity. - The above findings might be interpreted as suggesting that in late pregnancy an increased synthesis and secretion of glucagon augment the insulin secretory activity of the pancreas.

Diminution de l'insuline dans le pancréas du lapin

Résumé. Le contenu en insuline du plasma de lapins normaux et en gestation a été étudié par rapport à la quantité d'insuline qui pouvait être extraite de leurs pancréas. - Le contenu plasmatique moyen en insuline des lapins normaux, utilisés comme témoins, était de $25 \mu \mathrm{U} / \mathrm{ml}$ (entre 18 et 33) et l'insuline extraite de leurs pancréas était de $3.56 \mu \mathrm{g} / 100 \mathrm{mg}$ de tissu (entre 3.33 et 3.76). - Lorsque la gestation était à un stade avancé, le contenu en insuline dans le sang s'élevait à $56 \mu \mathrm{U} / \mathrm{ml}$ (entre 37 et 81 ), alors que l'insuline extraite du pancréas tombait à $1.17 \mu \mathrm{g} / 100 \mathrm{mg}$ de tissu (entre 0.65 et 1.73 ). L'ultrastructure des cellules A et B pendant la gestation a également été étudiée. La teneur des granules B en pendant la gestation avancée.

insuline diminue et les cellules A présentent des signes évidents d'une haute activité. - Les observations précédentes suggéreraient que lors de la gestation avancée, une synthèse et une sécrétion de glucagon accrues augmentent l'activité sécrétrice du pancréas en insuline.

Abnahme des Pancreas-Insulins beim Kaninchen während der fortgeschrittenen Schwangerschaft.

Zusammenfassung. Bei normalen und graviden Kaninchen wurden die Plasma-Insulinspiegel und das aus dem Pancreas extrahierbare Insulin gemessen. - Die mittleren Insulinspiegel der normalen Kontrolltiere lagen bei $25 \mu \mathrm{E} / \mathrm{ml}$ (zwischen 18-33), das Pankreasinsulin bei $3.56 \mu \mathrm{g} / 100 \mathrm{mg}$ Gewebe $(3.33-3.76)$. Die Seruminsulinspiegel steigen während der späten Schwangerschaftsstadien auf $56 \mu \mathrm{E} / \mathrm{ml}(37-81)$ an und das extrahierbare Pancreas-Insulin nimmt auf $1.17 \mu \mathrm{G} / 100 \mathrm{mg}$ Gewebe $(0.65-1.73)$ ab. - Wir untersuchten die Feinstruktur der Alpha- und Beta-Zellen während der Schwangerschaft: Dabei nahm das in den Beta-Granula gespeicherte Insulin ab und die Alpha-Zellen zeigten eindeutige Zeichen gesteigerter Aktivität. Die oben skizzierten Befunde könnten daraufhin deuten, daß während der späten Schwangerschaftsstadien eine gesteigerte Glucagon-Synthese und Sekretion die insulinsekretorische Aktivität der Bauchspeicheldrüse erhöht.

Key-words: Plasma insulin, Pancreatic insulin, Rabbit, Pregnancy, A-cells, B-cells, Electron microscopy, Glucagon.

It is frequently held that the changes in the endocrine system occuring during pregnancy have an effect on carbohydrate metabolism [28]. The frequent appearance of diabetes during pregnancy has been observed by several investigators $[14,8]$.

Some workers believe that tolerance for glucose is often impaired during pregnancy $[7,26]$. However, JACKSON [9] does not subscribe to this, having found no evidence of impairment of glucose tolerance in normal pregnancy. It is generally admitted that diabetes gets worse during pregnancy. On the other hand, the "temporary diabetes" of pregnancy rapidly improves after delivery.

Josimovitch and MacLaren [10] have suggested the existence of a specific diabetogenic factor of pregnancy. These authors showed the presence of a peptide in human retroplacental blood and urine to which they attribute hormonal properties. KAPLAN and Grumbacm [13] have quantitated this peptide in peripheral plasma.

We present here data for the insulin levels of peripheral plasma and pancreas in individual nonpregnant rabbits and rabbits during late pregnancy.

\section{Material and Methods}

Immunoassay. The determination of insulin was carried out following method $\mathrm{C}$ of HALES and RANDLE [6]. The bovine insulin used for standards in the immunological test was obtained from Eli Lilly Co., Indianapolis. Iodinated insulin-125I (Radiochemical Centre) was prepared from specially purified crystalline ox insulin (Borrough \& Co., potency 24.3 international units $/ \mathrm{mg}$ ) by iodination with iodine monochloride. Insulin-binding reagent was obtained from Wellcome Laboratories. Insulin concentration expressed as microunits or micrograms is given as bovine equivalent since bovine insulin has always been used as the standard for different samples.

Ten non-pregnant female rabbits $(1-1.5 \mathrm{~kg}$ body weight) and nine rabbits in the latter half of pregnancy (2-3 kg body weight) were studied. Rabbits were deprived of food for 18 hours but had free access to water. Blood samples were obtained from normal and pregnant rabbits decapitated after a blow on the head. Small amounts of heparin were added to prevent coagulation, and plasma was separated by centrifugation. 
Insulin from rabbit pancreas was extracted and partially purified according to CoORE and RANDLE [1]. The extract was then diluted in $0.04 \mathrm{M}$ phosphate buffer, $\mathrm{pH} 7.4$ to an appropriate final concentration.

Light microscopy. For light microscopic studies, the pancreas was fixed in Zenker-Formol and sections were stained with Hematoxilin-Eosin and AldehydeThionin [24], and counter-stained with Gomori [21].

Electron microscopy. For electron microscopic studies small pieces of the tail of the pancreas were fixed in distilled gluteraldehyde [3] with buffer Millonig, washed with the same buffer and postfixed for 2 hours in $2 \%$ osmium tetroxide and embedded in Epon 812 [20]. Sections were cut in the routine manner and stained with a combination of uranyl acetate and lead citrate [25]. The sections were examined with an electron microscope model Elmiskop I.

\section{Results}

Plasma insulin of normal and pregnant rabbits has been studied and compared with the extractable insulin of their pancreas. As shown in Table 1 the
The insulin levels in the blood increase during late pregnancy to $56 \mu \mathrm{U} / \mathrm{ml}$. The individual values given in the table show that the proportion of extractable pancreatic insulin decreases in each pregnant rabbit despite a small increase in the total weight of the pancreas.

By light microscopy most of the islets were of the usual size. Occasionally some that were larger than usual were encountered. With aldehyde-thionin the B-cells stained very lightly in relation to control islets. The A-cells, stained with the Gomori, were found in some islets to be of larger size than usual. No other alterations of the islets could be detected.

Electron microscopy - Normal rabbit pancreatic islets

Fine structure of A-cells: The A-cell of the rabbit pancreas has been described previously [22]. The Acells tend to be located near the periphery of the islet (Fig. 1). In electron micrographs A-cells can easily be distinguished from B-cells on the basis of the structure of the cytoplasmic granules as described by LACY [15]. The A-granules possess a dense internal portion se-

Table 1. Relationship between plasma insulin and extractable pancreatic insulin in normal and pregnant rabbits

\begin{tabular}{|c|c|c|c|c|c|}
\hline \multirow[t]{12}{*}{$\begin{array}{l}\text { Group } \\
\text { A }\end{array}$} & $\begin{array}{l}\text { non-pregnant } \\
\text { (controls) } \\
\text { Exp. }\end{array}$ & $\begin{array}{l}10^{\circ} \times \text { Concn. of } \\
\text { plasma-insulin } \\
\text { (i. } \mu / \mathrm{ml} \text { ) }\end{array}$ & $\begin{array}{l}\text { Concn. of } \\
\text { pancreas-insulin } \\
\mu \mathrm{g} / 100 \mathrm{mg} \text { tissue) }\end{array}$ & $\begin{array}{l}\text { pancreas } \\
\text { total weight } \\
\mathrm{g}\end{array}$ & $\begin{array}{l}\text { pancreas } \\
\text { total insulin } \\
\mu \mathrm{g}\end{array}$ \\
\hline & I & 25 & 3.54 & 1.09 & 38 \\
\hline & II & 30 & 3.76 & 1.20 & 45 \\
\hline & III & 33 & 3.57 & 1.30 & 46 \\
\hline & TV & 24 & 3.73 & 1.02 & 38 \\
\hline & $\mathrm{V}$ & 20 & 3.41 & 0.96 & 33 \\
\hline & VI & 32 & 3.33 & 0.80 & 27 \\
\hline & VII & 18 & 3.49 & 0.54 & 29 \\
\hline & VIII & 21 & 3.45 & 1.05 & 36 \\
\hline & IX & 28 & 3.73 & 1.30 & 48 \\
\hline & $\mathrm{X}$ & 18 & 3.65 & 0.70 & 26 \\
\hline & mean & $25 \pm 5$ & $3.56 \pm 0.15$ & $0.99 \pm 0.25$ & $37 \pm 8$ \\
\hline \multirow[t]{11}{*}{$\begin{array}{l}\text { Group } \\
\mathrm{B}\end{array}$} & $\begin{array}{l}\text { during late } \\
\text { pregnancy }\end{array}$ & & & & \\
\hline & $\mathrm{I}$ & 53 & 1.22 & 1.37 & 17 \\
\hline & II & 44 & 0.80 & 1.09 & 9 \\
\hline & III & 45 & 1.61 & 1.40 & 23 \\
\hline & IV & 60 & 1.05 & 1.37 & 14 \\
\hline & $\bar{V}$ & 81 & 1.28 & 1.32 & 17 \\
\hline & VI & 62 & 1.10 & 1.35 & 15 \\
\hline & VII & 37 & 1.73 & 1.15 & 20 \\
\hline & VIII & 48 & 0.65 & 1.05 & 7 \\
\hline & IX & 74 & 1.05 & 1.32 & 14 \\
\hline & mean & $56 \pm 14$ & $1.17 \pm 0.32$ & $1.26 \pm 0.13$ & $15 \pm 5$ \\
\hline \multicolumn{2}{|c|}{$P^{1}$ between $\mathrm{A}$ and $\mathrm{B}$} & $<0.001$ & $<0.001$ & $=0.01$ & $<0.001$ \\
\hline
\end{tabular}

Insulin values are given as equivalents of bovine insulin (potency 25 international units/mg) 1 Student's "t test".

mean plasma insulin of non-pregnant controls was $25 \mu \mathrm{U} / \mathrm{ml}$; extractable pancreatic insulin was $\mathbf{3 . 5 6}$ $\mu \mathrm{g} / 100 \mathrm{mg}$ tissue. parated by a less dense space from the distinct, closely applied, limiting membrane (Fig. 1 and 2). Most normal A-cells contain large numbers of such. 


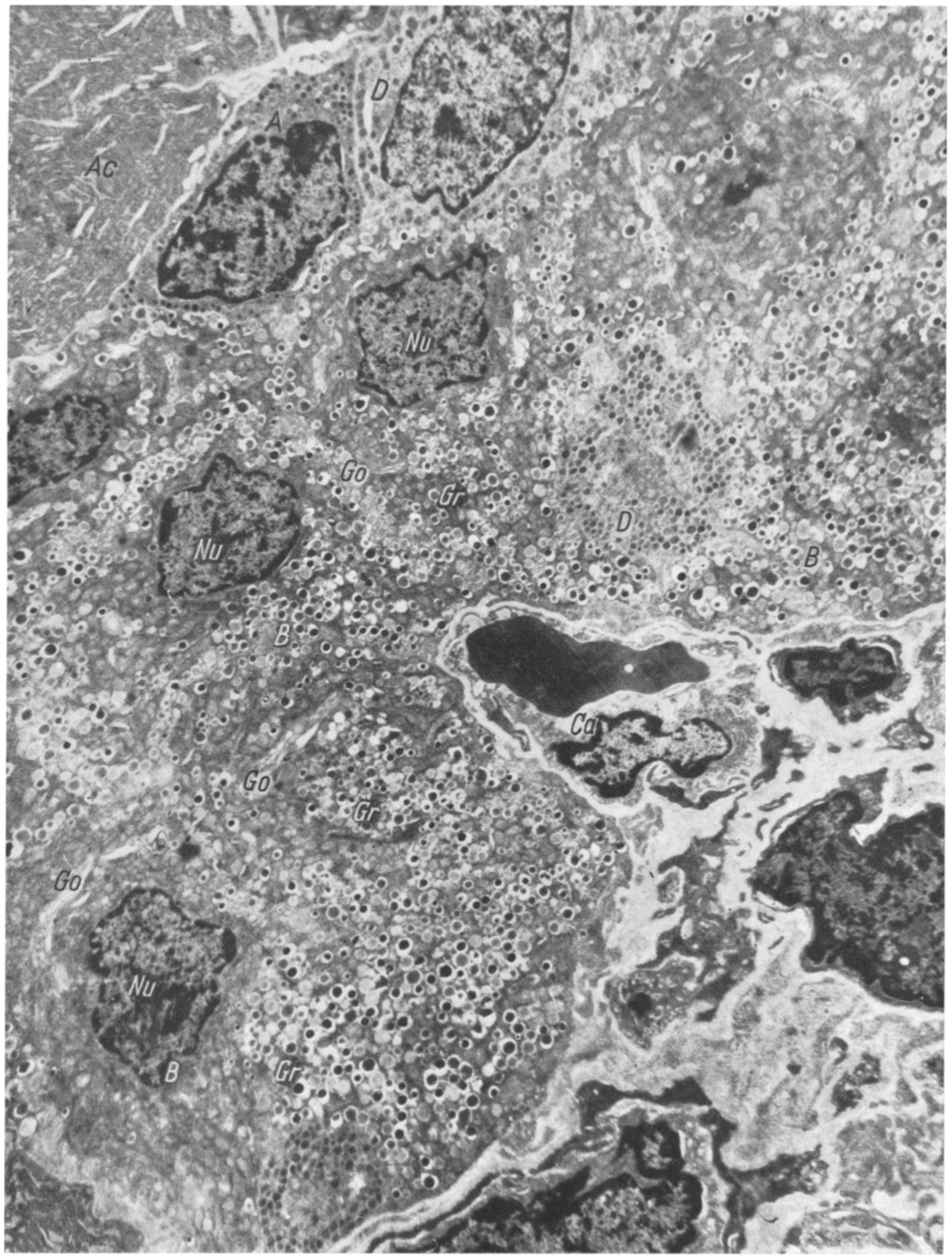

Fig. 1. Normal islet of the rabbit. B-cells (B) - B-secretory granules $(\mathrm{Gr})$ - Nuclei (Nu) - Golgi (Go) - A-cell (A) - D-cells (D) - Capillary (Ca) - Acinar cell (Ac) $-\times 6000$ 


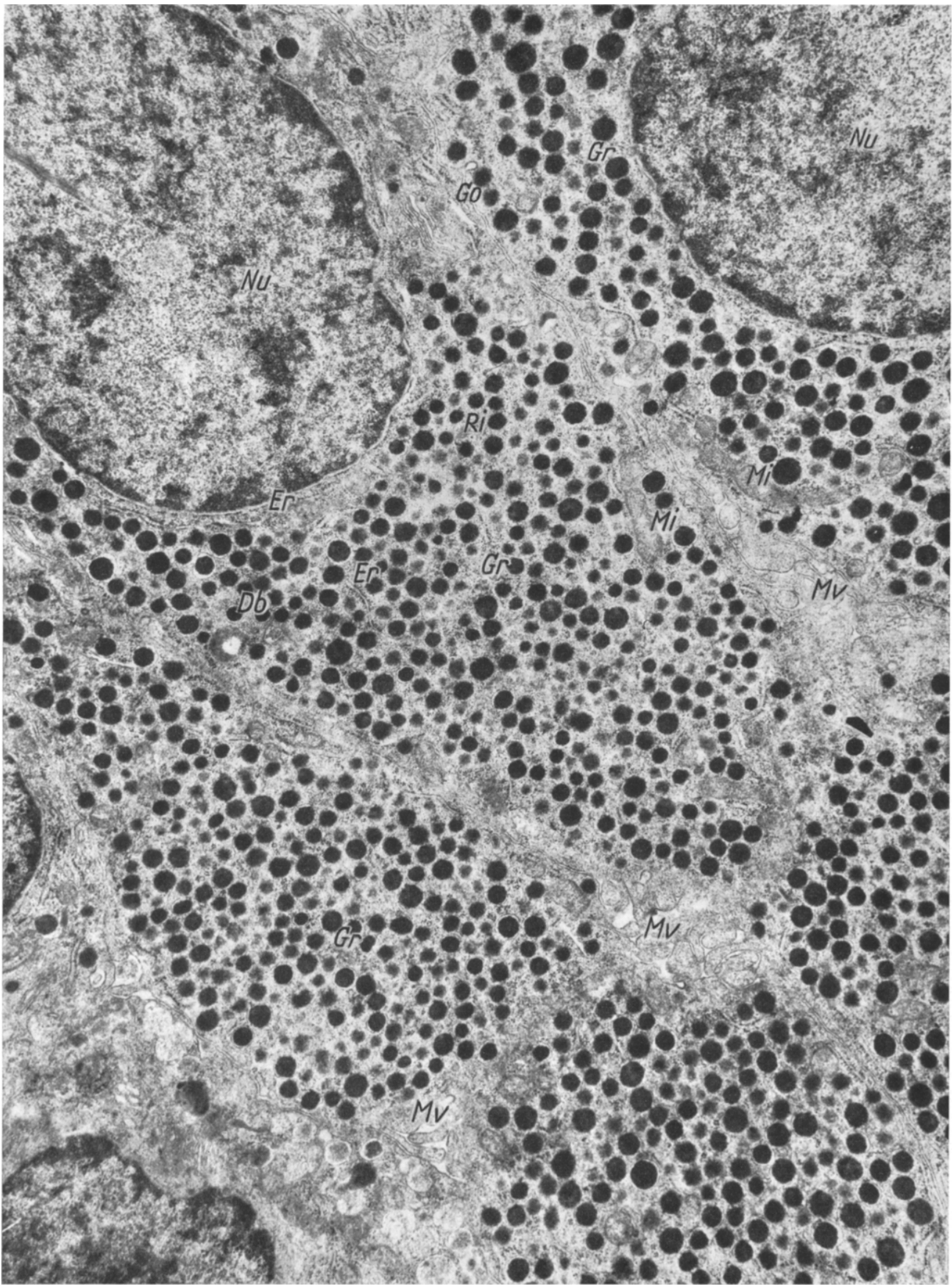

Fig. 2. Normal A-cells of the rabbit. Nuclei (Nu) - Lamellar Ergastoplasm (Er) - A-secretory granules (Gr) - Mitochondria (Mi) - Microvilli (Mv) - Golgi (Go) - Dense bodies (Db) - Ribosomes (Ri) - $\times 16500$ 


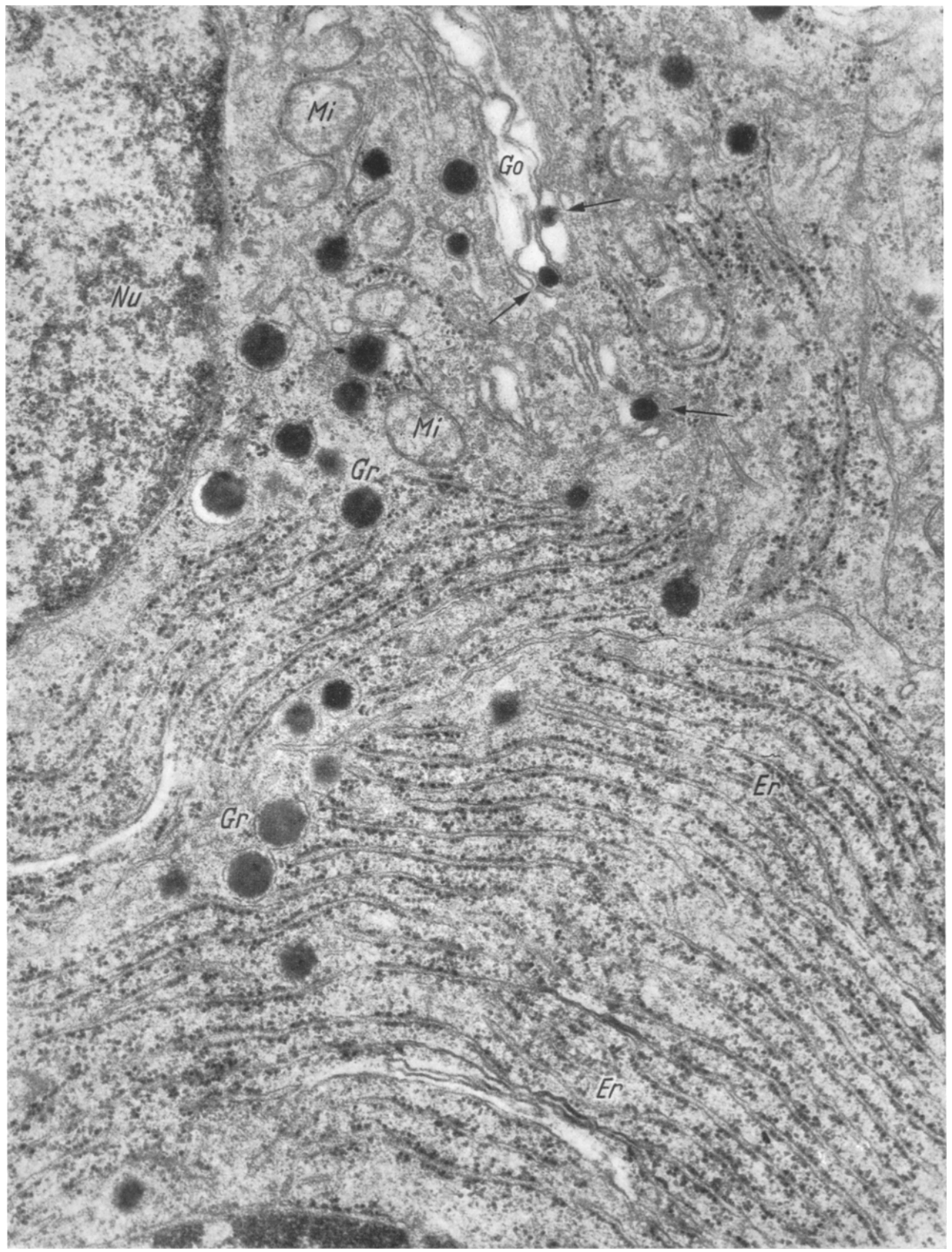

Fig. 3. Rabbit A-cells in late pregnancy. Nuclei (Nu) - Secretory granules (Gr) - Mitochondria (Mi) - Golgi (Go) - Secretory granules in agranular sacs of Golgi $(\rightarrow)$ - Lamellar ergastoplasm $($ Er $)-\times 32000$ 


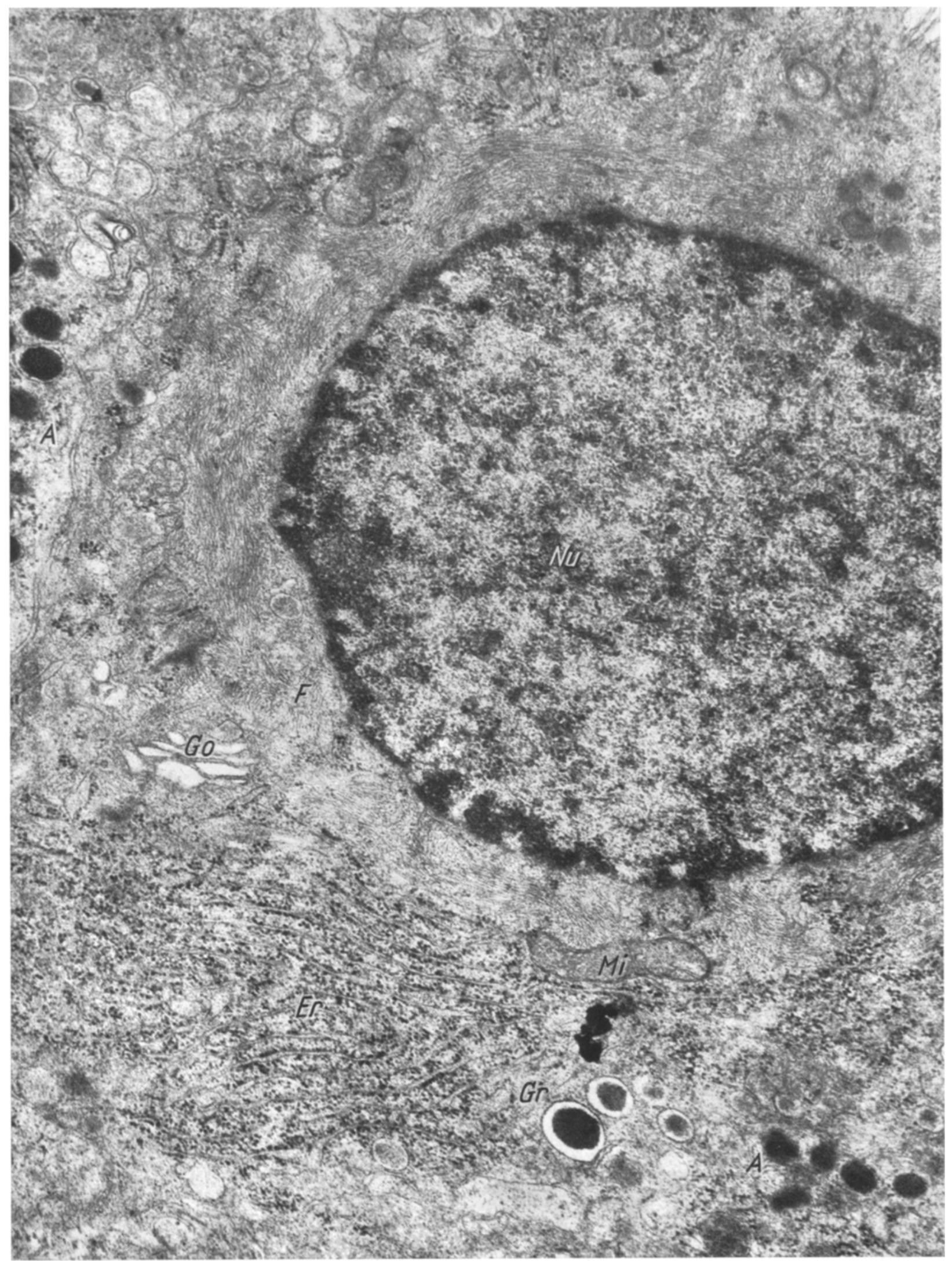

Fig. 4. Rabbit B-cell in late pregnancy. Nuclei (Nu) - Epithelial filaments (F) - Ergastoplasmic sacs (Er) Secretory granules (Gr) - Mitochondria (Mi) - Golgi (Go) - A-cells (A) $-\times 30000$ 
secretory granules filling the cytoplasm (Fig. 2). Other typical cytoplasmic organelles are present, consisting of a few flattened ergastoplasmic sacs, rod-shaped mitochondria; and dense bodies are quite often noticed. Bundles of delicate filaments are dispersed throughout the cytoplasm of the A-cells (Fig. 2).

Fine structure of B-cells: The fine structure of the B-cells has been described previously $[16,23,4]$. The cytoplasm of B-cells contains many secretory granules of uniform appearance. Epithelial filaments are usually present in a prominent band near the nucleus with no apparent relation with any of the organelles of the cell (Fig. 1). The other components of the cell are small distinct mitochondria, and ergastoplasm and prominent Golgi complexes.

\section{Rabbit pancreatic islet in late pregnancy}

Fine structure of $A$-cells: In this material many of the A-cells were lightly or moderately degranulated. These cells also showed a marked increase in the number of ergastoplasmic sacs and many granules could be detected in the agranular sacs of the Golgi apparatus (Fig. 3). No other changes could be noted.

Fine structure of B-cells: The major part of the $B$-cells in pregnant rabbits contained a smaller number of secretory granules than usual (Fig. 4). At the same time many showed an increase in ergastoplasmic sacs. No other changes could be detected except that in a few of the B-cells there was an increase in the number of mitochondria, which were occasionally of a larger size than average.

\section{Discussion}

The total insulin of the pancreas of pregnant rabbits is about one third of that of non-pregnant controls. Contrariwise the plasma insulin increases significantly during pregnancy.

The increase of circulating insulin observed during pregnancy in rabbits, confirms the results of LEAKE et al., [18]. The concomitant decrease of insulin in the pancreas indicates that in pregnancy this gland is in a state of continuous stimulation. This is consistent with the weight increase of the pancreas observed here, and with the finding [5] that in pregnancy the islets are enlarged or increased in number. SPELLACY and GoETz [27] reported that pregnancy regularly antagonizes the action of insulin and furthermore increases the insulin secretory capacity of the pancreas.

Since growth hormone produces degranulation and vacuolization of the B-islet cells [29] it is pertinent to consider bere if the increase of growth hormone occurring in pregnancy plays a role in the decrease of insulin found in the pancreas. According to DAUGHADAY and KIPNIS [2] many of the changes in carbohydrate metabolism that occur in pregnancy are remarkably similar to those described in acromegaly.

KaPLAN and GRUMBaCH have reported that a placental diabetogenic polypeptide is increased during pregnancy [12], but according to DaUghadaY and
Krpxis [2] the development of gestational diabetes does not seem to be an immediate consequence of an excesive increase of the placental growth hormonelike diabetogenic factor in plasma. However, this diabetogenic polypeptide has been suggested as the possible insulin antagonist in pregnancy $[2,11]$.

A characteristic degranulation of $B$ cells with the consequent decrease in the amount of insulin present in the pancreas is known to occur after the administration of glucagon to rabbits [17]. At present we do not know whether pregnancy influences the concentration of circulating glucagon. In this respect, the activity of the $A$ cells observed in our experiments would indicate that the synthesis and secretion of glucagon are increased. This could then stimulate the secretion of insulin. These findings might suggest a role of glucagon as an insulin antagonist during pregnancy, since it has been shown that intraportal infusion of glucagon inereases the plasma FFA levels in the peripheral blood [19].

Acknowledgements. The authors wish to thank Miss Patrocinio Lopez, Miss Luisa Maria Fernandez dei VAI and Mr. ELOY Blaxco for their invaluable technical assistance.

This work has been done thanks to a grant from the Dirección General de Sanidad (Madrid) and from Eli Lilly Co. Indianapolis.

\section{References}

[1] Cooke, H.G., and P. J. RANDLE: Regulation of insulin secretion studied with pieces of rabbit pancreas incubated in vitro. Biochem. J. 93, 66-78 (1964).

[2] Daughaday, W.H., and D.M. KIPNIS : The growthpromoting and anti-insulin action of somatotropin. Recent Progr. Hormone Res. 22, 49 - 99 (1966).

[3] Fahimi, H.D., and P. Drockmans: Essais de standardization de la fixation au gluteraldehyde. J. Microseop., 4, 125-736 (1965).

[4] Gomez-Acebo, J., C. Lopez-Qutuada and J.L. R-CaNDELA: Fine structure of B-cells from pancreas pieces incubated in vitro. Diabetologia 2, 110-116 (1966).

[5] Grodsky, G.M. and P.H. Forsham: Insulin and the pancreas. Ann. Rev. Physiol. 28, 352-371 (1966).

[6] Hales, C.N., and P.J. Randele: Immunoassay of insulin with insulin antibody precipitate. Biochem. J. 88, 137-146 (1963).

[7] Hurwitz, D., and D. Jensear : Carbohydrate metabolism in normal pregnancy. New Engl. J. Med. 234, $327-339$ (1946).

[8] Jackson, W.P.U.: On Diabetes Mellitus: Diabetogenic effects of pregnancy. Springfield, IIl.: Charles C. Thomas. p. $1 \overline{6} 2,1964$.

[9] - : Studies in prediabetes. Brit. med. J. 1952 II, $690-698$

[10] Josmmovitch, J.B., and J.A. MacLaren: Presence in the human placenta and term serum of a highly lactogenic substance immunologically related to pituitary growth hormone. Endocrinology 71, 209220 (1962).

[11] KaLkHoFf, R., D.S. Schalch, J.L. Walker, P. Beck, D.M. Kipnis and W.H. DaughadaY: Diabetogenic factors associated with pregnancy. Trans. Ass. Amer. Phyens 77, 270-279 (1964).

[12] KaptaN, S.L., and M.M. GRUMBaCr: Serum chorionic "growth hormone-prolactin" and serum pituitary growth hormone in mother and fetus at term. J. clin. Endocrin. 74, 1370-1374 (1965). 
[13] - - : Studies of a human and Simian placental hor mone with growth hormone-like and prolactin-like activities. J. clin. Endocr. 24, 80-100 (1963).

[14] Katsch G.: Schwangerschaft als Belastungsprobe für Diabetikerinnen. Zbl. Cynalk., 24 A. 1756 (1950).

[15] LACY, P.E.: Electron microscopy of the beta cell of the pancreas. Amer. J. Med. 31, 851-859 (1961).

[16] - Electron microscopic identification of different cell types in the islets of Langerhans of the guinea pig, rat, rabbit and dog. Anat. Rec. 128, 255-261 (1957).

[17] Lazarus, S.S., and B.W. Vouk: The effect of protracted glucagon administration on blood glucose and on pancreatic morphology. Fndocrinology 63, 359371 (1958).

[18] LeAKE, N.H., and R.L. BurT: Insulin-like activity in serum during pregnancy. Diabetes 11, 419-431 (1962).

[19] LefEBvRe, P.: The physiological effect of glucagon on fat mobilisation. Diabetologia 2, 130-132 (1966).

[20] LuFT, J.H.: Improvements in epoxy-resin embed. ding methods. $J$, biophys. biochem. Cytol. II, 736742 (1961).

[21] Gomorr, G. : Manual of Histologic and special staining technics. A.F.I.P. Second edition. GoMorI's one step trichrome stain (Amer. J. clin. Path. 20, 661-664 (1950). The Blakiston Division. McGrawhill Book Company Inc., p. 66 (1960).

[22] Munger Bryce, L.: The secretory cycle of the pancreatic a-cell. Lab. Invest. II, 885-892 (1962)
[23] - I. CARAMIA and P. LACY: The ultrastructural bases for the identification of different cell types in the islets of Langerhans of the guinea pig, rat, rabbit and dog. Z. Zellforsch. 67, 776-798 (1965).

[24] Paget, G. E.: Aldehyde-Thionin, a stain having similar properties to Aldehyde-Fuchsin. Stain Technol. 34, 223-229 (1959).

[25] Reynolds, E. L.: The use of lead citrate at high $\mathrm{pH}$ as an electron opaque stain in electron microscopy. J. Cell Biol. 17, 1-208 (1963).

[26] Silverstone, F.A., E. Solomons and J. Rubriotos: The rapid intravenous glucose tolerance test in pregnancy. J. clin. Invest. 40, 2180-2192 (1961).

[27] Spfllacy, W.N., and F.C. Goetz: Plasma insulin in normal late pregnancy. New Engl. J. Med. 268, $988-995$ (1963).

[28] Ten Berge, B.S.: Pregnancy: Chemistry and Management. Springfield, Ill., Charles C. Thomas. p. 153, 1964.

[29] Volk, B.W., and S.S. Lazarus: Ultramicroscopic evolution of B-cell destruction in diabetic dogs. Wonner-Grenn Center: International Symposium Series. V. 3. The structure and Metabolism of the Pancreatic Islets. Oxford: Pergamon Press. p. 155, 1964.

C. Lopez-QuiJada, M.D.

Instituto "G. Marañon"

Consejo Superior de

Investigaciones Cientificas

Velazquez 144

Madrid, Spain 